\title{
Transregionalism and fictive capital
}

\author{
Daria Dinetc ${ }^{1, *}$, and Mikhail Konotopov ${ }^{2}$ \\ ${ }^{1}$ Irkutsk state transport university,Department of economics ang management on transport ISTU, \\ 664074, 15 Chernishevsky st., Irkutsk, Russia \\ ${ }^{2}$ Russian academy of engineer, 125009, 9 Gazetny pereulok 9, Moscow, Russia
}

\begin{abstract}
A relevance of research is recent trend in regrouping forces in the global financial arena with transregional unions based on fictive capital' expansion. The objective of this research is revisal of transregional integration conditions by the analysis of modern geopolitical aims of the world financial system's leaders and also it is practical recommendations forming to prevent the Russian economy trapping by the fictive capital of transregional unions. It has been shown that the global finance circulation model is drastically changing - trade and economic unions like the Regional Comprehensive Economic Partnership or Transatlantic Trade and Investment Partnership are aimed at forming the markets for goods, works and services produced in countries, which have been proclaimed as the world financial centres. That politics doesn't allow to develop industry and it arrive to financial bubbles at branches of economy, which are cooperated with transregional financial flows. For the leaders of transregional groups, it's a way to solve geopolitical problems with financial methods shifting responsibility for their mistakes in industrial policy. There are significant features of the east and west leaders dominance in transregional unions in the article. These are respectively hub infrastructure dependence and currency speculations. The conclusion is it should be formed a secured non-speculative currency in transregional union for geopolitical dependence eliminate. Besides the only reason for infrastructure international project realize could be an economic efficiency. These conclusions are very important for the modern stage of the globalization.
\end{abstract}

\section{Introduction}

The object of management is not the supply and the level of costs, but the possibility of the demand generation for products and services offered by the leading countries of world trade. And in this context, two practical aspects of common markets formation energy, with the participation of Russia, are important:

1. The common market assumes the presence of a larger number of buyers than sellers on it. Currently developed models of common markets include mainly commodity sellers and transport services. The model is not viable, the level of costs for competition in such a market will exceed all the possible benefits from the merger;

\footnotetext{
*Corresponding author: dardinets@gmail.com
} 
2. while the most important players have focused their efforts on demand management, it seems that it is necessary to find reserves for managing costs. Only economic efficiency will allow to counteract global changes in the movement of value chains. In other words, if the directions of the movement of added value are determined by the trends in the development of transregional groupings, then it is necessary to manage the level of added value in export positions through internal measures.

The present period itself gives unlimited opportunities for the development of the Russian economy: unlike the trade and economic leaders of the West and East, Russia has no crisis of overproduction or overaccumulation of capital. Under such conditions, supply management can become a key to the growth of competitive advantages at the initial stages of the development of a new technological order.

The growth of transport services export due to involvement into international transport corridors is complicated by the presence of geopolitical contradictions between Russia and the trans-regional blocs located in the East (Regional Comprehensive Economic Partnership) and the West (Transatlantic Trade and Investment Partnership). The situation is complicated by the fact that there are serious political disputes between these blocs, complicated by the realization that direct trade wars for European markets between the West and the East will lead to the ruin of transnational corporations, which is contrary to the interests of all participants in international trade.[1]

In these conditions, the search for compromises in the direction of trade and financial flows becomes the only possible strategy for all parties involved in the process of redistribution of power in international trade. In these conditions, the search for compromises in the direction of trade and financial flows becomes the only possible strategy for all parties involved in the process of redistribution of power in international trade.

\section{Materials and methods}

The paper is based on comparing and system analysis methods application to identify causal relationships between fictive capital flows and world transregionalization process. Besides international financial statistics was summarized and systematized in the context of transregional unions. Description of international financial and trade flows allows to form the main prerequisites of the research, which follows next. Also research was based on regulatory information, especially in international energy trade.

It is worth mentioning the following main geopolitical trends, which were confirmed with the statistical analysis:

1.the intention of the North American countries to expand the export of shale oil and LNG to Europe and drive out Russia from the respective markets;

2.the formation of gas hubs in Europe, the priority of hub pricing with the establishment of prices "here and now" depending on the level of demand and supply for the relevant resources, the refusal to conclude long-term contracts linked to the prices of the oil basket;

3.the formation of free access for all market participants to the gas transmission and transmission network infrastructure, the requirement to transfer gas transmission infrastructure and transmission capacity to independent operators (operators of backbone networks).

The listed difficulties are dictated by the norms of the third energy package of the EU, where requirements are set for providing a free competitive energy market with the possibility of equal access to this market for all generating and transmission companies, while the functions of generation, transmission and distribution of energy should be divided between essentially different and independent companies. In other words, the main focus of the contradictions between the countries of the Transatlantic partnership and Russia is on 
the energy transport corridors, which should become international, that is, provide national access for residents of other countries.[2]

Table 1 shows the main types of energy markets depending on the competition models adopted on them.

Table 1. Types of energy markets.

\begin{tabular}{|l|l|l|}
\hline $\begin{array}{c}\text { A type of } \\
\text { energy }\end{array}$ & $\begin{array}{c}\text { Competition } \\
\text { market }\end{array}$ & $\begin{array}{c}\text { Non- } \\
\text { competition } \\
\text { market }\end{array}$ \\
\hline Electricity & $\begin{array}{l}\text { SIEPAC, } \\
\text { Nord Pool, } \\
\text { EU market }\end{array}$ & $\begin{array}{l}\text { Garabi, } \\
\text { Mecong }\end{array}$ \\
\hline Gas & $\begin{array}{l}\text { Gaspoint } \\
\text { Nordic, EU } \\
\text { market, } \\
\text { NAFTA }\end{array}$ & MERCOSUR \\
\hline
\end{tabular}

\section{Results and discussion}

The basic principles of the competitive liberal model of the international energy market:

1. Separation of functions of production (generation), transportation and distribution of energy.

2.Diversification of energy supplies.

3. Hub trade and pricing, refusal to index gas contracts for oil prices.

4. Spot market, the rejection of long-term contracts.

5. Prohibitions and restrictions on the formation of reserves by energy sellers.

6. Free access of all participants to the gas transportation or electric grid infrastructure.

7. The liquid market for derivative financial instruments (trade in surplus, overload, futures, etc.).

8. Lack of protectionism.

Obviously, this model is unacceptable for Russia, but there is an opinion that the EU's requirements for the formation of free transport corridors and exchange trade throughput are not entirely consistent. Indeed, with the use of hub pricing, the risks for companies engaged in the construction of infrastructure for energy transport corridors are extremely high, and the desire of companies to expand the gas transmission or network infrastructure is questionable.[3]

Only China, which is unlikely to be admitted to the European transmission and distribution markets, is able to make such investments, while Russia's Gazprom, due to the notorious economies of scale, does not experience difficulties in paying off investments in the gas transportation infrastructure. It seems that with this development of events, it is necessary to organize an international energy hub in Kaliningrad with a focus on European consumers to formally eliminate contradictions with the norms of the third energy package.

Additional imbalances in the development of energy transportation are made by the desire of US companies to seize European gas markets through the expansion of LNG extracted from hard rocks. Again, one can note with caution that the "conditional advantage" is on the side of Russia because of the inconsistency of the policies applied by Western countries. LNG, imported from the US to Europe, is significantly more expensive than gas coming from pipelines from Russia. At the same time, Europe at the expense of excessive enthusiasm for financial bubbles has deprived itself of a cost inflation mechanism that allowed economic inefficiency to be shifted to the consumers' shoulders. If the plans for a large-scale expansion of American LNG into European markets are realized, then the share of energy resources in the cost of products produced in Europe will increase, while 
the growth of prices for these products will be limited by the prices for more competitive American goods. As a result, there will be a need for additional financial resources, which, it is not difficult to guess, will come to the European financial markets from America. That is, in conditions of overproduction, the American side will finance the acquisition by Europeans of its goods and services. The further scenario is well known: European companies that are massively attracting financial capital on the Eurodollar market will lose inefficient at a given price level for energy resources, they will lose in the ratings, the capitalization of European markets will decrease, the imminent threat of default will push the company to convert liabilities into shares, and ultimately the ownership of European capital will be redistributed in favor of American TNCs. However, the struggle is being waged with Gazprom's monopoly, and not with the probability of a collapse of the next financial bubble.[4]

Quick analysis of current economic unions let us make some disappointing conclusions in terms of Russia and Eurasian Economic Union. Both eastern and western integration unions tend to centralize the world trade on their own terms. Without significant reforms in foreign trade, Russia might become an exporter of transport services with the risk of loosing sovereignty over transport infrastructure: in Asia because of China's investments control, and in Europe - due to the necessity to handover gas infrastructure to independent operators to decrease the level of Gazprom's monopoly.

In addition geographical location of Russia doesn't allow organizing a similar trade union, because there are no enough countries with different types and structures of goods and services' production and trade to make it possible for Russia to organize an international trade union that will be competitive enough.

Also the Russian Federation has a full access to the North-South transport corridor, and this advantage must be used in a discussion of including Eurasian Economic Union into the system of international trade as an independent and legally competent agent.

However, before describing different models of international markets organization, we should consider the data on international trade between countries, included in TTIP and RCEP in a more detailed way, as these political unions play as buyers and sellers in «One belt - one road».

Having compared the trade volumes of the USA, the EU and Asian countries, it can be noticed that the export potential of Asian countries significantly exceeded the volumes of TTIP in 2016 (only trade in goods has been considered, the services of property capital and transactional sector have been excluded from consideration).

The second deduction is the trade volume inside the unions exceeds the volume of trans regional trade despite its priority in foreign policies of different countries.

Hence, China and the USA attempt to interfere in regional international trade by imposing upon the models of transregional partnership, and securing preferential access to both trade and finances as well as to negotiation leverage in politics.

To achieve this, however, China and the United States use various instruments: the US, following cross-border trade expansion, pursues a policy of imposing its fictitious capital, having in its arsenal the Eurodollar market, and China is being building supply chains to create distribution channels for its products.

All mentioned above occurs against a backdrop of increasing tensions over the free passage of warships through the canals that are the inland waters of Third Countries.

As for the contradictions between Russia and the countries belonging to the TAPP, the eastern countries, which are affected by the crisis of overproduction, implement investment projects that provide the infrastructure for trade in their goods, and strive to maintain control over this infrastructure. As a payment for the implementation of investment projects for the development of international transport corridors, preferential treatment and (or) ownership of the energy resources produced in Russia is established. 
Among other things, Asian projects are also implementing hub projects to promote Chinese goods with lower costs due to economies of scale. It seems that to achieve these goals in the plans of the Chinese side and in the framework of the OBOR initiative, the following hubs are planned:

1. Singapore, South Korea - trading with the APR,

2.Kazakhstan - trading with the Caspian countries, the countries of the Persian Gulf, Pakistan, India, then - the countries of South America,

3. Iceland - trading with European and North American countries.

Such a regime of investment interaction threatens national sovereignty and contributes to the stagnation of the Russian economy. Moreover, the investment resources received by the country in such a regime lead to the fact that transport becomes a rental industry and falls out of the system of expanded reproduction of social capital, involving in the circulation of financial capital, which becomes fictitious capital without the possibility of reinvestment.

The formation of rent in the transport sector means that the Russian side receives its revenues only from the fact that it carries out transport construction on its territory for the carriage of goods by the country that finances the project. In other words, the economic content of such relations is reduced to receiving rent from the provision of land lease services. Further, since the infrastructure built without the export of transport services to Asian partners is excessive, there is no possibility of reinvesting the received rent, therefore, it is highly likely that these funds will be directed to the financial markets where another financial bubble is being formed. The situation is complicated by the fact that many calculations are still carried out in dollars, that is, dependence on the US economy manifests itself even in operations with eastern partners.

Therefore, we consider that the current model of attracting Chinese investments is an additional source of risk of losing sovereignty over the objects of transport infrastructure and intensifying the withdrawal of capital. If transport construction is carried out with the purpose of involving in the international transport corridor, then the approach to project evaluation should differ from the assessment of strictly infrastructural projects, that is, transport construction should be paid for by increasing the volume of export of transport services, without taking into account GDP multipliers, social effects and so on. . If the project is not repayable, then its implementation will lead to the withdrawal of capital.

In this context, we also approach the need to manage the supply, cost structure and economic efficiency as the only way to preserve the sovereignty of value added in spite of global trends of its redistribution with the help of international transport corridors and energy platforms.

The preliminary conclusion is that, through the implementation of projects for the construction of international transport corridors and energy platforms, the US and China are shaping markets for their goods and capital, and neocolonialism can clearly be traced in attempts to control markets, despite the fact that the basis is different instruments. There is also an obvious similarity - the architecture of the offshore yuan market is very close to the eurodollar market architecture. In both cases, these are tools for repatriating the liquidity of investment projects.

The level of domestic value added in the US exports is steadily falling. Available data for 2014 indicate that the United States is the last among the OECD countries in terms of the national value added in the export of goods. At the same time, it is proved that the lower the level of national added value in foreign trade, the lower the level of employment in the economy. As for China, the low level of added value in the export of this country was previously perceived as a competitive advantage, whereas today the country is looking for reserves to increase the level of wages, and therefore, the share of value added in exported goods, to maintain domestic demand at an acceptable level. 
The role of hubs, including energy, and international transport corridors in achieving the goals of expansion of domestic value added in products manufactured in the US appears to be the possibility of increasing the liquidity of the respective markets, with the subsequent transfer of this liquidity to financial markets, including for export of financial services. That is, if the Chinese model consists in pumping out the rent by financing it for the acquisition of Chinese goods and services, the American one is the transformation of the energy and transport markets into financial ones, on which the unified lots are sold, into which integrated transport solutions traded through hubs (similar to how synthetic mortgage products were once "packaged"). This is due to the complete unification of transport and logistics services, enabling the trading of certain impersonal conventional units - lots of unified transport and logistics services, regardless of the geography of the movement of goods or the geography of the extraction of natural resources. Accordingly, unified lots can be resold unlimited number of times, thus forming a so-called liquid and competitive market. By the way, the single energy market in Europe has a minimum number of resale, in which the market is considered liquid. This number is 8 shifts of the owners before the transfer to the end user. At the same time, it is asserted that such a scheme will allow setting lower prices for final consumers, rather than under long-term contracts of Gazprom

The main result of research is revealing of fictive capital' sources which are destroyful for transregional unions' efficiency. These sources are currency speculations and floating exchange rate instruments and also non-efficiency infrastructure projects. It allows to transfer costs with fictive capital to other countries included to transregional union.

\section{Conclusion}

Summing up the comparison of the western and eastern models of managing international transport corridors, it should be noted that despite the different instruments, the final objectives are similar in many ways - using the potential and economic resources of other countries to overcome internal crises. In the case of China - through the establishment of infrastructure dependence and the withdrawal of rents in exchange for Chinese goods, in the case of the United States - due to the redistribution of liquidity and the expansion of opportunities for speculation in the markets.

The revealed peculiarities of the behavior of key figures determining the development processes of the international transport corridor services market make it possible to formulate conditions that will allow Russia to become an active player in this market, rather than a party receiving land rent, as certain transport lines pass through its territory. To such conditions it is possible to carry:

1. Evaluation of the economic efficiency of the implementation of projects focused on the export of transport services. Refusal of all indirect indicators characterizing the effectiveness of infrastructure projects. In conditions of involvement in international transport corridors, the project can not be regarded as strictly infrastructural.

2. Establishment of reinvestment opportunities for profits received from the implementation of the transport construction project. Such an opportunity should be confirmed by the availability of investment tools in projects aimed at increasing the number of redistributions in related technological chains. The alignment of vertical links is thus a prerequisite.

3. Engagement of the potential of the North-South corridors, Indiga port, Sviyazhsky intermodal center, the Baltic-Volga-Caspian corridor. Formation of own hubs, which allow to obtain a positive scale effect, and also to involve potential buyers in the markets of the Arctic natural resources. 
4. Formation of reverse logistical flow within the country and to the East. Wide involvement of BAM in integration processes (Taishet - Komsomolsk-on-Amur).

5. Using the potential of the North-South corridors for transporting Arctic energy resources - eliminating seasonal unevenness and diversifying supplies. For example, the European region consumes most of its energy resources in winter, while southern Asian countries consume much of their energy in the summer, when air conditioners are active.

6. Forming a network of joint energy hubs within a single market, but involving key buyers. Presumably, in Kaliningrad, Kazakhstan, Yamal and Vladivostok. Use of high level of uncertainty of changes in hub prices for energy resources in Europe. The introduction of a settlement system based on the unit of account tied to national currencies.

7. Establishment of energy and transport dialogue not only with Eastern countries, but also resolution of disputes in the traditional markets of Europe with the goal of combining efforts against the expansion of American fictitious capital.

Thus, it seems necessary to form its own model of the general market for transport services, including the energy transportation market. In this situation it is impossible to make an unambiguous conclusion about the acceptability of this or that model of the energy and transport market. Only through the use of the most acceptable elements of different models can the processes of global capital redistribution be overcome by the transregional associations of the East and the West.

\section{References}

1. N. P. Tereshina, V. V. Zhakov, Tenth International Conference Management of LargeScale System Development (MLSD) (2017)

2. V. Malygin, V. Komashinsky, V. V. Tsyganov, Tenth International Conference Management of Large-Scale System Development (MLSD) (2017)

3. G. A. Agasandyan, Tenth International Conference Management of Large-Scale System Development (MLSD) (2017)

4. E. A. Grebenyuk, Tenth International Conference Management of Large-Scale System Development (MLSD) (2017)

5. N. A. Lebedev, Int. J. Econ. Fin. Issues, 6, 300-305 (2016)

6. N. A. Lebedev, A. G. Paptsov, T. V. Butova, Revis. Espac. Digit. 38, 29 (2017) ISSN 07981015

7. N. A. Lebedev, A. N. Alexeev, A. N. Savenkov, Financial problems of regional development and the ways of their solution in contemporary Russia // http://www.srac.ro/calitatea/en/arhiva/supliment/2018/Q-asContents_Vol.19_S2_July2018.pdf .

8. S. Zhiltsov, V. Shtol, V. Egorov, Energy flows in central Asia: Issues and outlook, 18, 52-61 (2017)

9. V. I. Blishchenko, V. G. Egorov, D. N. Ermakov, S. Ya. Lavrenov, V. V. Shtol and O. A. Zozulya, Democ. Anthol. Top. Probl. Soc. Sci. 11, 5347-5359 (2016)

10. C. Corrado, J. Haskel, C. Jona-Lasinio, Product. Growth Cap. Reall. Fin. Crisis Evid. EU US J. Macroecon. https://www.sciencedirect.com/science/article/ pii/S0164070418301149 